\title{
YENI MUTASYON SAPTANAN GM1 GANGLİOSİDOZ OLGUSU
}

\author{
GM1 GANGLIOSIDOSIS CASE WITH NEW MUTATION
}

Zahide YALAKİ ${ }^{1}$, Gizem ER AKPINAR ${ }^{1}$, Abdüllatif BAKIR ${ }^{2}$

\section{ÖZET}

GM1 gangliosidoz, gangliosidlerin intralizozomal birikimi ile karakterize bir hastaliktır. Burada yeni mutasyon saptanan GM1 gangliosidoz olgusu sunuldu. On aylık erkek hasta pnömoni tanısı ile yatırıldı. Fizik muayenesinde; gelişim geriliğii, burun kökü basık, kaba yüz görünümü ve düsük kulakları vardı. Her iki gözde beyaz refle, pektus ekskavatum takipne, raller, hepatosplenomegali, tırnaklarda distrofi, ayak birinci parmakta tetik parmağ hipotonisitesi vard. Destekli ve desteksiz oturamıordu, baş kontrolü yoktu ve katı gıdaları yutamıyordu. Karaciğer enzim testleri yüksek idi, idrar-kan aminoasitleri, idrarda redüktan madde negatif bulundu. Vertebralarda yükseklik kaybı ve kifoz vardı. Katarakt cerrahisinden sonra tekrar bakılan göz muayenesinde 'Japon bayrağı' görünümü saptandı. Genetik incelemesinde daha önce saptanmayan GLB1 geninde homozigot c.1719delT değişimi tespit edildi. Bu olguyu sunarak GM1 gangliosidoz hastalığında yeni mutasyona ve prenatal tanıya dikkat çekmek istedik.

Anahtar kelimeler: Infant, GM1 gangliosidoz, prenatal tanı

\section{GİRİS}

Gangliosidler, herediter geçişli lizozomal depo hastalığıdır ve GM1, GM2 gangliosidoz olmak üzere iki alt tipi bulunmaktadır. Bu tiplerden birincisi olan GM1 gangliosidoz, lizozomal beta-galaktozidaz enziminin eksikliği sonucu gelişen GM1 gangliosidlerin intralizozomal birikimi ile karakterize bir hastalıktır. Beta-galaktozidaz enziminin kodlandığı GLBL geninde meydana gelen homozigot veya birleşik heterozigot mutasyonlarla oluşan otozomal resesif geçişli bir hastalıktır. İnsidansı 100 000200000 canlı doğumda bir olarak saptanmıştır (1-3). Hastalığın infantil, juvenil ve erişkin tipi olmak üzere üç farklı klinik tipi bulunmaktadır. İnfantil formu (Tip 1); doğumla- 6 ay arasında hipotoni, santral sinir sisteminde dejenerasyon, hepatosplenomegali ile karakterize hızlı

\begin{abstract}
GM1 gangliosidosis is a disease characterized by intralysosomal deposition of gangliosides. Here, we present a case of GM1 gangliosidosis in which a novel mutation was detected. A 10-monthold male patient was admitted with pneumonia. In physical examination; growth retardation, nasal root flattened, rough face appearance and low ears. Both eyes had white reflex, pectus excavatum, tachypnea, raller, hepatosplenomegaly, nail dystrophy, hypotonicity and trigger finger in the first toe. He could not sit with or without support, had no head control and could not swallow solid food. Liver enzyme tests were high; urine-blood amino acids and urinary reductants were found to be negative. Vertebras had loss of height and kyphosis. The eye examination after cataract surgery revealed a 'Japanese flag' appearance. In the genetic examination, homozygous c.1719delT change was detected in the GLB1 gene, which was not previously detected. By presenting this case, we wanted to draw attention to novel mutation and prenatal diagnosis in GM1 gangliosidosis disease.
\end{abstract}

Keywords: Infant, GM1 gangliosidosis, prenatal diagnosis

ilerleyen 1-2 yaşlarında ölümle sonuçlanan formudur. Juvenil form (geç infantil veya tip 2); 7 ay-3 yaş arasında başlar. Yavaş ilerleme gösteren psikomotor gelişme geriliği, hipotoni, hepatosplenomegali ile karakterizedir. Erişkin tipi ise (tip 3); 3-30 yaş arasında görülür. Yavaş ilerleyen Parkinson bulguları, demans, ekstrapiramidal bulgular, distoni gözlenir. Erişkin tip GM1 gangliosidoz Japon ırkında daha sık bildirilmektedir $(4,5)$.

Burada yeni mutasyonun saptandiğı infantil tipte klinik özellikler gösteren GM1 gangliosidoz olgusu sunuldu.

\section{OLGU}

On aylık erkek hasta öksürük ve ateş nedeni ile çocuk acil polikliniğine getirildi. Hastanın muayenesinde ta-

${ }^{1}$ S.B Ankara Eğitim ve Araştırma Hastanesi, Çocuk Sağlığı ve Hastalıkları Kliniği, Ankara, Türkiye.

${ }^{2}$ S.B Dr. Zekai Tahir Burak Kadın Sağlığı Eğitim ve Araştırma Hastanesi, Genetik Bölümü, Ankara, Türkiye.

Geliş Tarihi / Submitted : Aralık 2019 / December 2019

\section{Sorumlu Yazar / Corresponding Author:}

Zahide YALAKI

S.B.Ü Ankara Eğitim ve Araştırma Hastanesi, Çocuk Sağlığı ve Hastalıkları Kliniği,

Ulucanlar/ANKARA

Gsm: +905064079866

E-posta: dr_zahide@yahoo.com
Kabul Tarihi / Accepted : Mart 2020 / March 2020 
kipne ve bilateral raller olması nedeni ile çocuk servisine pnömoni tanısı ile yatırıldı. Özgeçmişinde 19 yaşındaki annenin takipli ilk gebeliğinden zamanında normal vajinal yol ile 2600 gr doğduğu, üç aylıkken brid ileus nedeni ile opere edildiği, 5 ve 7 aylıkken pnömoni nedeni ile dış merkez çocuk servis ve çocuk yoğun bakımda yatırılarak izlendiği öğrenildi. Soygeçmişinde; anne ve babanın birinci derece kuzen olduğu, ailede bilinen hastalık olmadığ durumu iyi, vücut ağırlığı: 5950 gram $(<3$ p) burun kökü basık, kaba yüz görünümü ve düşük kulakları vardı. Her iki gözde beyaz refle, pektus ekskavatum ve karaciğer 3 $\mathrm{cm}$, dalak $1 \mathrm{~cm}$ palpabl, el ve ayak tırnaklarında distrofi, her iki ayak birinci parmakta tetik parmağ ve hipotonisitesi mevcuttu. Destekli ve desteksiz oturamadığı, ayına göre baş kontrolünün olmadığı, katı gidaları yutamadığı görüldü. Hastanın mevcut pnömonisi için tedavisi başlanırken aynı zamanda eşlik eden gelişim geriliği, atipik yüz görünümü, patolojik bulgularına yönelik olarak ileri tetkikler planlandı. Bakılan biyokimyasal parametreleri içinde AST:203 U/L ALT:200U/L, tam kan sayımı, böbrek fonksiyon testleri ve tiroid fonksiyon testleri normal idi. Nörometabolik hastalık şüphesi ile idrar-kan aminoasitleri, Tandem Mass Spektrometri ( MS), idrarda redüktan madde tetkikleri çalışıldı. Tetkikleri normal olarak saptandı. Çekilen kranial manyetik rezonans (MR) görüntülemenin ve elektroensefalografinin (EEG) normal olduğu görüldü. Yapılan ultrasonografik incelemelerde karaciğer, dalak normal boyutlarda görülüp her iki böbrekte milimetrik kristaloidler saptandı. Skolyoz şüphesi olan hastaya yapılan torakolomber MR'da; L2 vertebra anterior kesiminde yükseklik kaybı, L1-2 düzeyinde kifoz saptandı. Hastanın pnömonisi düzeldikten sonra katarakt nedeni ile opere oldu. Operasyon sonrasi yapılan göz dibi muayenesinde 'Japon bayrağı' görüntüsü saptandı. Klinik açıdan GM1 gangliosidoz ile benzerlik gösteren hastada periferik kan örneğinden elde edilen DNA'da yapılan moleküler genetik analizle GLB1 gen mutasyonu araştırıldı. Hastada GLB1 geninde homozigot c.1719delT değişimi tespit edildi (Şekil 1).
Belirlenen değişiklik literatürde daha önce bildirilmemiş olmakla birlikte, çerçeve kaymasına neden olması ve erken stop kodon oluşturması nedeni ile hastalık ile ilişkili (patolojik) varyant olarak değerlendirildi. Genç aileye genetik danışma ve prenatal tanı hakkında bilgi verilmek üzere genetik bölümüne yönlendirildi.

\section{TARTIŞMA}

GM1 gangliosidoz gelişiminden sorumlu olan beta-galaktozidaz enzimi GLB1 geni ile kodlanmaktadır ve bu enzim hücre lizozomu içinde glikoproteinlerden, sfingolipitlerden ve keratin sülfattan galaktoz rezidülerini ayıran enzimdir. GM1 gangliosidozda enzim aktivitesi azalmıştır. Beyin ve visseral hücrelerin lizozomlarında GM1 gangliosid birikir $(5,6)$. Beta-galaktozidaz enziminin aktivitesinin derecesi klinik belirtilerin başlama yaşını ve hastalığın şiddetini belirlemektedir $(4,5,7)$.

Literatürde infantil tip GM1 gangliosidoz hastalarında rezidüel beta-galaktozidaz enzim aktivitesi \%0,07-1,3 bulunurken, juvenil tipte $\% 0,3-4,8$, erișkin tipinde ise \%9 olarak bulunduğu bildirilmektedir. Enzim aktivitesi ne kadar az olursa klinik de o kadar ağır olmakta ve bulgular daha erken ortaya çıkmaktadır(8).

Bizim hastamızda da anamnezde üç aylıktan sonra başlayan tekrarlayan akciğer enfeksiyonları, nöromotor gelişme geriliği, hepatosplenomegali, katarakt, lumbal kifoz gibi bulgular olduğu öğrenildi. Ayrıca anne-baba arasında akrabalık bulunması nedeniyle hastada nörometabolik hastalıklar yönünden inceleme yapıldı, idrar ve kan aminoasitleri, idrar organik asitleri, idrarda mukopolisakkarit taramaları normal olarak bulunurken, hastanın patolojik bulguları ve başlangıç zamanı değerlendirildiğinde GM1 gangliosidoz ile uyumlu olabileceği düşünüldü. Bu nedenle bakılan genetik taramasında da GLB1 geninde yeni mutasyon tanımland.

Hastamızda literatürle uyumlu olarak klinik bulgular mevcuttu. Bununla birlikte Yüksel ve ark.(9) belirttiği gibi

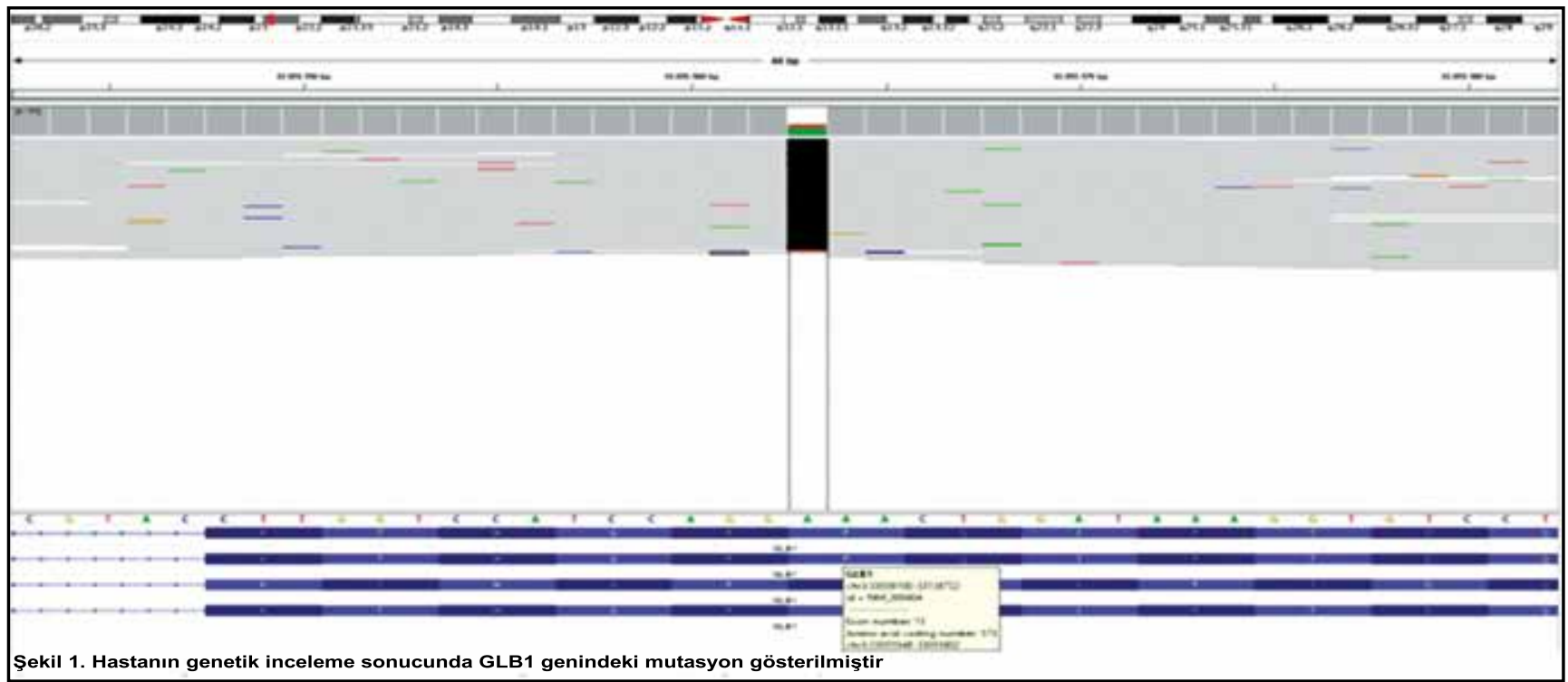


yaygın mongol lekeleri bulunmamaktaydı. Biyokimyasal incelemesinde karaciğer fonksiyon testlerinde yükseklik bulunmaktaydı. Kılıç ve ark.(3) infantil gangliosidoz hastalarında AST yüksekliğinin önemli bir parametre olduğunu belirtmişlerdir. Bizim hastamızda da vardı.

İnfantil tipte gangliosidoz hastalarında kaba yüz görünümü, frontal bossing, basık ve geniş burun kökü, düşük kulaklar, dilde hipertrofi, eller kaba, parmaklar kısa olabilmektedir. Torakal kifoz, kifoskolyoz gelişebilmektedir $(4,5)$. Hastamızda da kifoz, yüz anomalisi, göz bulguları olarak katarakt ve kiraz kırmızısı retina bulunmaktaydı. Yüksel ve ark’nın (10) bildirdiği olguda konvülziyon da eşlik ederken bizim hastamızda konvülziyon yoktu. Yapılan EEG de normal idi. Ancak nöromotor gelişimi ciddi derecede geri idi. Hipotonisite ve baş tutmasının olmaması ile birlikte yutma disfonksiyonu da bulunmaktaydı. Bu nedenle mikroaspirasyonlar olmakta sonuçta sık akciğer enfeksiyonu gelişmekteydi.

Hastalıktan sorumlu enzimi kodlayan GLB1 geni 3.kromozomda bulunmaktadır (9). Bu gende 102 mutasyon tanımlanmaktadır. Bu mutasyonların 78'i missense/nonsense, $10^{\prime} \mathrm{u}$ splicing mutasyon, 7 'i insersiyon ve 7'i delesyon mutasyonları olarak bildirilmektedir $(1,5,10)$. Hastamızda ise daha önce bildirilmeyen yeni mutasyon saptanmış olup çerçeve kaymasına neden olması ve erken stop kodon oluşturması hastalık ile ilişkili olarak değerlendirildi. Bu açıdan hastamızın sonucunun klinik tanıyı teyid ettiği düşünüldü.

Hastalığın spesifik tedavisi bulunmamakta ve bu hastaların büyük kısmı iki yaşından önce kaybedilmektedir. Genetik geçişi olan bu hastalığın önlenebilmesi için daha sonraki gebelik planlamasında aileye genetik danışma verilmesi, taşıyıcılık tespit edilmesi durumunda preimplantasyon genetik tanı (PGT) ile gebelik elde edilmesi önerilmektedir. Preimplantasyon genetik tanı yaptıran hastalarda sağlıklı gebeliğin teyidi için ve yaptıramayan tüm hastalara da amniosentez/koryonik villüs örneklerinde enzimatik veya genetik analiz yapılarak prenatal tanının konulması önerilmektedir (7).

Makale/olgu sunumu herhangi bir kongrede sunulmamıştır.

\section{KAYNAKLAR}

1.)Sinigerska I, Chandler D, Vaghjiani V, et al. Founder mutation causing infantile GM1- gangliosidosis in the Gypsy population. Mol Genet Metab 2006; 88 (1): 93-95.

2.)Platt FM, Boland B, Spoel AC. Lysosomal storage disorders: The cellular impact of lysosomal dysfunction. J Cell Biol 2012; 199(5): 723-34.

3.)Kılıç M, Kasapkara ÇS, Kılavuz S, Mungan NÖ, Biberoğlu G. A possible biomarker of neurocytolysis in infantile gangliosidoses: aspartate transaminase. Metab Brain Dis 2019; 34(2): 495-503.

4.) Vanier MT, Caillaud C, Levade T. Sphingolipidosis. In: Saudubray JM, Baumgartner MR, Walter J (eds) Inborn metabolic diseases, diagnosis and treatment, 6 th edn. Springer, Berlin, Heidelberg, 2016: 556-566.

5.)Brunetti-Pierri N, Scaglia F. GM1 gangliosidosis: review of clinical, molecular, and therapeutic aspects. Mol Genet Metab 2008; 94(4): 391-6.

6.)Tessitore A, Martin P, Sano R, et al. GM1-ganglioside-mediated activation of the unfolded protein response causes neuronal death in a neurodegenerative gangliosidosis. Mol Cell. 2004; 15 (5): 753-766. 7.)Pastores GM, Kolodny EH. Lysosomal storage disease. In: Swaiman KF, Ashwall S, Ferriero DM, (eds). Pediatric Neurology: Pricipres and Practive, (4th ed). Philadelphia: Mosby Elsevie, 2006: 659-714.

8.)Okumiya T, Sakuraba H, Kase R, Sugiura T. Imbalanced substrate specificity of mutant beta-galactosidase in patients with Morquio B disease. Mol Genet Metab. 2003; 78 (1): 51-58.

9.)Yüksel D, Öksüz Ş, Şenbil N. Yaygın mongol lekelerinin eşlik ettiği GM1 gangliosidosis türü: Bir vaka takdimi. Çocuk Sağlığ ve Hastalıkları Dergisi 2007; 50(3): 189-192.

10.)Santamaria R, Chabas A, Coll M.J, Miranda C.S, Vilageliu L, Grinberg D. Twenty-one novel mutations in the GLB1 gene identified in a large group of GM1-gangliosidosis and Morquio B patients: possible common origin for the prevalent p. $\mathrm{R} 59 \mathrm{H}$ mutation among gypsies, Hum Mutat. 2006; 27(10): 1060.

Ankara Eğt. Arş. Hast. Derg. (Med. J. Ankara Tr. Res. Hosp.), 2020 ; 53(1) : 73-75

Olgu sunumu olduğundan Etik Kurul Onayı gerekmemektedir.Hastanın Velisi'nden Yayın için yazılı izin alınmıştır. 